\title{
Serological Survey of Bovine Coronavirus in Korea
}

\author{
Dong-Kun Yang ${ }^{1, *}$, Chang-Hee Kweon ${ }^{1}$, Byoung-Han Kim ${ }^{2}$, Jeong-Kyu Park ${ }^{1}$, \\ Byung-Jae So ${ }^{1}$ and Jae-Young Song ${ }^{2}$ \\ ${ }^{1}$ Animal Disease Diagnosis Division, ${ }^{2}$ Virology Division, National Veterinary Research and \\ Quarantine Service, 480 Anyang 6-dong Anyang, Gyeonggi-do 430-824, Korea
}

Received : March 13, 2007

Accepted: June 12, 2007

\begin{abstract}
Bovine coronavirus $(\mathrm{BCoV})$ is a causative agent of entero-pathogenic diarrhea in young calves and winter dysentery (WD) in adult cattle. In this study, we conducted a nationwide sero-epidemiological survey of $\mathrm{BCoV}$ infection in Korea. In total, 3,029 bovine sera collected between October and December 2005 were screened for the presence of antibodies against $\mathrm{BCoV}$ using a hemagglutination inhibition (HI) test. Half $(50.0 \%)$ of individual cattle tested were positive for $\mathrm{BCoV}$. The regional distribution of the seroprevalence of positive $\mathrm{HI}$ antibodies was $55.7 \%$ (234/420) in Gyeonggi, 53.0\% (316/596) in Jeonra, 51.9\% (374/720) in Chungcheong, 48.5\% (401/827) in Gyeongsang, 43.9\% (79/180) in Jeju, and 38.1\% (109/286) in Gangwon Province. Analyzing the distribution of HI titer according to the age of the cattle showed the highest $\mathrm{BCoV}$ seropositive rate in 5-year-old cattle, and the incidence of cattle with an $\mathrm{HI}$ antibody titer of $1: 160$ or above was $12.1 \%$.
\end{abstract}

Key Words: Bovine coronavirus, Seroepidemiology, Korea

\section{INTRODUCTION}

Bovine coronavirus ( $\mathrm{BCoV})$, a coronavirus, is a spherical, enveloped virus that ranges from 80 to $160 \mathrm{~nm}$ in diameter. The $\mathrm{BCoV}$ genome consists of a single linear molecule of positive sense RNA, approximately $31 \mathrm{~kb}$ long. It encodes the viral RNA-dependent RNA polymerase and the four major structural proteins (15). The peplomeric (S) and hemagglutinin (HE) proteins can cause hemagglutination (HA) with rat or mouse erythrocytes and are thought to be involved in protecting cattle from infection with $\mathrm{BCoV}(13$, 17). $\mathrm{BCoV}$ is a common agent in neonatal calf diarrhea (CD) and is associated with winter dysentery (WD) in adult cattle, which causes large economic losses such as decrea-

\footnotetext{
* This work was supported by a grant from NVRQS, Korea.

${ }^{* *}$ Corresponding author: Dong-Kun Yang. National Veterinary Research and Quarantine Service, 480 Anyang 6-dong Anyang, Gyeonggi-do 430-824, Korea.

Phone: +82-31-4671792, Fax: +82-31-4671868,

e-mail: yangdk@nvrqs.go.kr
}

sed milk production $(2,21)$. $\mathrm{BCoV}$ also possesses a tissue tropism for the upper respiratory tract (14). Although there are minor antigenic and biological variations among $\mathrm{BCoVs}$ from $\mathrm{CD}$ and $\mathrm{WD}$ strains based on the clinical symptoms $(4,12)$, it has been thought that there is only one $\mathrm{BCoV}$ serotype $(9,14,21)$. BCoV infections in cattle have been reported in many countries throughout the world, including Korea $(3,13)$ and have also been observed in other ruminants such as sheep, mules, and white-tailed deer $(20,21)$. Various serological assays such as virus neutralization (VN) tests, hemagglutination inhibition (HI) tests, indirect immunofluorescence (IF) tests, and enzyme linked immunosorbent assays (ELISA) have been used to assess levels of antibody to $\mathrm{BCoV}(17,18)$. HI tests have been used to describe cow and calf serological status for $\mathrm{BCoV}$ in Canada (6) and have shown a high correlation with $\mathrm{VN}$ tests using sera obtained from cattle vaccinated with inactivated $\mathrm{BCoV}$ (17). Seroepidemiological surveys of $\mathrm{BCoV}$ are important, because the survey data could be used for setting up vaccination programs and initiating measures to prevent 
virus transmission. Although $\mathrm{BCoV}$ infections in the cattle industry have been reported in many countries throughout the world, nationwide sero-epidemiological surveillance of $\mathrm{BCoV}$ infection in Korea has not been performed. In this study, bovine sera collected nationwide were screened for the presence of antibodies against BCoV using an $\mathrm{HI}$ test.

\section{MATERIAL AND METHODS}

\section{Virus and cells}

BCoV strain KV0501 used in this study was isolated in Korea in 2005 from feces of naturally-infected calf. The $\mathrm{BCoV}$ had been passaged 5 times in HRT-18 cells that were derived from a human rectal adenocarcinoma. For the propagation of the $\mathrm{BCoV}$, monolayered HRT-18 cells were rinsed twice with PBS and then inoculated with trypsintreated $\mathrm{BCoV}$. After adsorption at $37^{\circ} \mathrm{C}$ for $1 \mathrm{~h}$, the cultures were incubated in $\alpha$-MEM containing $0.5 \mu \mathrm{g} / \mathrm{ml}$ of crystallized bovine trypsin (Sigma St. Louis, Mo, USA) until a $\mathrm{BCoV}$ specific cytopathic effect was seen. After three freeze-thaw cycles, the harvested virus was clarified by centrifugation for $30 \mathrm{~min}$ at $3,000 \mathrm{xg}$ to remove cell debris. The crude $\mathrm{BCoV}$ was used as the antigen in the $\mathrm{HI}$ test.

\section{Hemagglutination inhibition (HI) tests}

For the seroprevalence survey, serum samples were obtained from 3,029 cattle from 1,118 farms in six provinces of Korea between October and December 2005. The
HI test was carried out according to standard microtiter procedures using mouse red blood cells $(11,16)$. Briefly, for removing non-specific inhibitors, $100 \mu \mathrm{l}$ of serum and 500 $\mu \mathrm{l}$ of PBS were mixed with $400 \mu \mathrm{l}$ of $25 \%$ kaolin (Sigma). After shaking for $1 \mathrm{~h}$, kaolin was removed by centrifugation of 12,000 rpm for $5 \mathrm{~min}$ in a microfuge. Clear supernatant was mixed with $50 \mu \mathrm{l}$ of packed normal mouse erythrocytes to remove natural agglutinins. After incubation for $1 \mathrm{~h}$ at $37^{\circ} \mathrm{C}$, the treated serum was separated from mouse erythrocytes by centrifugation. For HI test, four to eight HA units of $\mathrm{BCoV}$ (in $25 \mu \mathrm{l}$ ) were added to $25 \mu \mathrm{l}$ of the treated sera. After incubation for $1 \mathrm{~h}$ at $37^{\circ} \mathrm{C}, 50 \mu \mathrm{l}$ of $1 \%$ mouse erythrocytes were added. The plates were incubated at $4{ }^{\circ} \mathrm{C}$ for $90 \mathrm{~min}$. The HI titer was expressed as the reciprocal of the highest dilution of serum showing complete inhibition of hemagglutination. The serum samples showing HI titer equal to or greater than 1:20 were considered positive (6).

\section{Statistical analysis}

Chi-square tests were used to analyze the differences in seroprevalence between the breed, genders, age, and regions, respectively. A p-value less than 0.05 was considered to be statistically significant.

\section{RESULTS}

The average prevalence of antibodies against $\mathrm{BCoV}$ was $50.0 \%$ in 3,029 serum samples (Table 1). The regional

Table 1. Cattle population and regional distribution of $\mathrm{BCoV}$ antibodies from cattle in Korea

\begin{tabular}{|c|c|c|c|c|c|c|c|}
\hline \multirow{2}{*}{ Breed } & \multicolumn{6}{|c|}{ Province } & \multirow{2}{*}{ Total } \\
\hline & $\mathrm{GG}^{*}$ & GW & $\mathrm{CC}$ & GS & $J R$ & $\mathrm{JJ}$ & \\
\hline Holstein & $108 / 156$ & $4 / 7$ & $50 / 106$ & $63 / 137$ & $70 / 131$ & $30 / 70$ & $325 / 607$ \\
\hline$\%$ & 69.2 & 57.1 & 47.2 & 46.0 & 53.4 & 42.9 & 53.5 \\
\hline Population $(\%)^{\dagger}$ & 38.9 & 4.0 & 21.5 & 16.9 & 15.3 & 1.1 & 97.7 \\
\hline Korean native & $126 / 264$ & $105 / 279$ & $324 / 614$ & $338 / 690$ & $246 / 465$ & $49 / 110$ & $1,188 / 2,422$ \\
\hline$\%$ & 47.7 & 37.6 & 52.8 & 49.0 & 52.9 & 44.6 & 49.1 \\
\hline Population (\%) & 6.9 & 8.3 & 19.6 & 32.5 & 26.5 & 1.0 & 94.8 \\
\hline Total & $234 / 420$ & $109 / 286$ & $374 / 720$ & $401 / 827$ & $316 / 596$ & $79 / 180$ & $1,513 / 3,029$ \\
\hline$\%$ & 55.7 & 38.1 & 51.9 & 48.5 & 53.0 & 43.9 & 50.0 \\
\hline
\end{tabular}

${ }^{*}$ GG; Gyeonggi, GW; Gangwon, CC; Chungcheong, GS; Gyeungsang, JR; Jeonra, and JJ; Jeju, respectively.

${ }^{\dagger}$ Data was obtained from Agricultural and forestry statistical year book, National Agricultural Product Quality Management Service (March 1, 2006), Korea. 
Table 2. Age distribution of $\mathrm{HI}$ titer against $\mathrm{BCoV}$

\begin{tabular}{cccc}
\hline \hline \multirow{2}{*}{$\begin{array}{c}\text { Age of } \\
\text { cattle }\end{array}$} & $\begin{array}{c}\text { No. of positive } \\
(\%)\end{array}$ & $\begin{array}{c}c \\
\text { HI titer }\end{array}$ \\
\cline { 3 - 4 } & & $\begin{array}{c}1: 20 \sim 1: 80 \\
(\%)\end{array}$ & $\begin{array}{c}\geq 1: 160 \\
(\%)\end{array}$ \\
\hline 1 & $68 / 144(47.2)$ & $53(38.6)$ & $15(10.4)$ \\
2 & $381 / 847(45.0)$ & $293(34.7)$ & $87(10.3)$ \\
3 & $587 / 1,137(51.6)$ & $446(39.2)$ & $141(12.4)$ \\
4 & $296 / 554(53.4)$ & $223(40.3)$ & $73(13.2)$ \\
5 & $100 / 184(54.3)$ & $77(41.8)$ & $23(12.5)$ \\
$\geq 6$ & $81 / 163(49.7)$ & $55(33.7)$ & $26(16.1)$ \\
\hline \multirow{2}{*}{ Total } & $1,513 / 3,029$ & $1,148 / 3,029$ & $365 / 3,029$ \\
& $(50.0)$ & $(37.9)$ & $(12.1)$ \\
\hline
\end{tabular}

distribution of the seroprevalence of a positive $\mathrm{HI}$ titer was $55.7 \%$ (234/420) in Gyeonggi, 53.0\% (316/596) in Jeonra, $51.9 \%$ (374/720) in Chungcheong, 48.5\% (401/827) in Gyeongsang, 43.9\% (793/180) in Jeju, and 38.1\% (109/286) in Gangwon Province. We found no significant differences of the seropositive rate between native Korean (49.1\%) and Holstein dairy $(53.5 \%)$ cattle in all regions except for Gyeonggi where significant difference $(\mathrm{p}<0.05)$ was observed.

Analyzing the distribution of $\mathrm{HI}$ titer against $\mathrm{BCoV}$ according to the age of the cattle showed the highest seropositive rate in 5-year-old cattle (54.3\%). The incidence of cattle showing an $\mathrm{HI}$ antibody titer above $1: 160$ was $12.1 \%$ (Table 2). Female cattle showed significantly higher seroprevalence $(50.8 \% ; 1355 / 2665)$ than males $(43.4 \% ; 158 /$ $364)$. Seroprevalence was significantly higher $(\mathrm{p}<0.05)$ in females $(50.8 \%$; $1355 / 2665)$ than males $(43.4 \% ; 158 / 364)$. Of the cattle that had an $\mathrm{HI}$ antibody titer of 1:20 or more, the most frequent $\mathrm{HI}$ titer was 1:40 (13.8\%; Fig. 1).

\section{DISCUSSION}

$\mathrm{BCoV}$ infection has been reported in most cattle-raising countries, and its seroprevalence has been estimated to range from $61 \%$ in Sweden to $90 \%$ in Canada $(2,13,20)$. Antibodies to $\mathrm{BCoV}$ have also been detected in several other species, such as sheep, white-tailed deer, and pigs, with the prevalence ranging from 6.6 to $44.2 \%(8,20,21)$. $\mathrm{BCoV}$ is antigenically related to murine hepatitis virus, hemagglutinating encephalomyelitis virus, rat virus, and

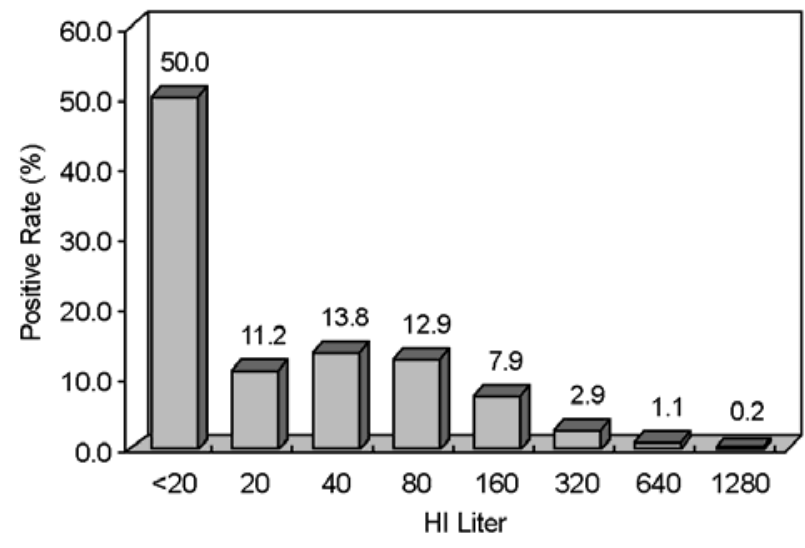

Figure 1. Frequency of distribution of HI titer in 3,029 serum samples collected from Korean cattle.

human coronavirus OC43. But the virus does not crossreact the other bovine viruses (19). Several studies have reported $\mathrm{BCoV}$ s isolated from the feces of calves and cows in Korea $(3,10)$. Jeong et al. (10) reported consistent detection of $\mathrm{BCoV}$ from all herds with winter dysentery in Korea during 2002-2004. By using BCoV antigen-capture ELISA, 34 of 97 (35.1\%) fecal samples were found to be positive. Of the 32 herds tested, 17 herds (53.1\%) showed BCoV-positive fecal samples (10). Since calf diarrhea and winter dysentery cause enormous economic losses in the cattle industry in Korea $(3,10)$, we wanted to estimate the nationwide infection rate of cattle with $\mathrm{BCoV}$ by performing an $\mathrm{HI}$ test on bovine serum from Korean cattle. Although $\mathrm{BCoV}$ has been classified as a single serotype (14), some reports described antigenic variations among $\mathrm{BCoV}$ strains $(5,7,22)$. BCoV strains hemagglutinated both mouse and chicken erythrocytes at $4^{\circ} \mathrm{C}$. All strains agglutinated mouse erythrocytes at $4^{\circ} \mathrm{C}$ with similar HA titers $(7,22)$, but the $\mathrm{HA}$ titers were different according to $\mathrm{BCoV}$ strains used when chicken erythrocytes were used. Therefore in this study, recently isolated BCoV KV0501 strain and mouse erythrocytes were used for $\mathrm{HI}$ test. The regional prevalence ranged from $38.1 \%$ to $55.7 \%$, depending on the province. As shown in Table 1, seroprevalence of $\mathrm{BCoV}$ in Holstein was the highest in Gyeonggi province, which showing the highest Holstein cattle population. Since a $\mathrm{BCoV}$ vaccine has been used to prevent wild infection in the Korean cattle population, this seroprevalence result may not represent the true prevalence of $\mathrm{BCoV}$ infection. Although the exact $\mathrm{BCoV}$ vaccination status of cattle in Korea is not known, 
the use of a BCoV vaccine seems to be very limited. About $130,000 \sim 170,000$ doses of BCoV live vaccine are produced annually in domestic veterinary biological companies (1). The serological survey results indicate that cattle seropositive for $\mathrm{BCoV}$ are evenly distributed throughout the country. Takamura et al. (17) reported that cattle with an HI antibody titer $\leq 1: 80$ and an SN titer $\leq 1: 160$ developed severe clinical signs such as watery diarrhea and fever after challenge. Therefore, mucosal infection with $\mathrm{BCoV}$ can be prevented if the HI titer of $\geq 1: 160$ or the SN titer of $\geq 1$ : 640 is present in the blood (17). In this study, only $12.1 \%$ of cattle were found to have an $\mathrm{HI}$ antibody titer of 1:160 or above, indicating that a large number of cattle (about $88 \%$ ) are faced with the danger of wild $\mathrm{BCoV}$ infection associated diarrhea or respiratory syndrome; therefore, effective vaccination should be practiced to elevate cattle immunity to $\mathrm{BCoV}$.

\section{Acknowledgements}

We thank Ms. Choi SS for technical assistance and Dr. Lee KW for the statistical analysis.

\section{REFERENCES}

1) 김병한: 최근 3 년간 동물용생물학적제제 수급동 향. 수의과학검역정보지 24: 67-76, 2004.

2) Alenius S, Niskanen R, Juntti N, Larsson B: Bovine coronavirus as the causative agent of winter dysentery: serological evidence. Acta Vet Scand 32: 163-170, 1991.

3) Chung CW, CHo JJ, Cho IS, An SH, Jang MS: Isolation and characterization of Bovine coronavirus from calves and adult cows with diarrhea. RDA $J$ Veterinary Sci 39: 11-18, 1997.

4) El-Ghorr AA, Snodgrass DR, Scott FM, Campbell I: A serological comparison of bovine coronavirus strains. Arch Virol 104: 241-248, 1989.

5) Fukutomi T, Tsunemitsu H, Akashi H: Detection of bovine coronaviruses from adult cows with epizootic diarrhea and their antigenic and biological diversities. Arch Virol 144: 997-1006, 1999.

6) Ganaba R, Belanger D, Dea S, Bigras-Poulin M: A seroepidemiological study of the importance in cowcalf pairs of respiratory and enteric viruses in beef operations from northwestern Quebec. Can J Vet Res
59: 26-33, 1995.

7) Hasoksuz M, Lathrop SL, Gadfield KL, Saif LJ. Isolation of bovine respiratory coronaviruses from feedlot cattle and comparison of their biological and antigenic properties with bovine enteric coronaviruses. Am J Vet Res 60: 1227-1233, 1999.

8) Hirano N, Ono K: A serological survey of human coronavirus in pigs of the Tohoku District of Japan. Adv Exp Med Biol 440: 491-494, 1998.

9) Hussain KA, Storz J, Kousoulas KG: Comparison of bovine coronavirus (BCV) antigens: monoclonal antibodies to the spike glycoprotein distinguish between vaccine and wild-type strains. Virology 183: 442-445, 1991.

10) Jeong JH, Kim GY, Yoon SS, Park SJ, Kim YJ, Sung CM, Jang OJ, Shin SS, Koh HB, Lee BJ, Lee CY, Kang MI, Kim HJ, Park NY, Cho KO: Detection and isolation of winter dysentery bovine coronavirus circulated in Korea during 2002-2004. J Vet Med Sci 67: 187-189, 2005.

11) Kapil S, Richardson KL, Maag TR, Goyal SM: Characterization of bovine coronavirus isolates/from eight different states in the USA. Vet Microbiol 67: 221 $-230,1999$.

12) Ko CK, Kang MI, Lim GK, Kim GY, Yoon SS, Park JT, Jeong C, Park SH, Park SJ, Kim YJ, Jeong JH, Kim SK, Park SI, Kim HH, Kim KY, Cho KO: Molecular characterization of HE, M, and E genes of winter dysentery bovine coronavirus circulated in Korea during 2002-2003. Virus Genes 32: 129-136, 2006.

13) O'Connor A, Martin SW, Nagy E, Menzies P, Harland R: The relationship between the occurrence of undifferentiated bovine respiratory disease and titer changes to bovine coronavirus and bovine viral diarrhea virus in 3 Ontario feedlots. Can J Vet Res 65: 137-142, 2001.

14) Reynolds DJ, Debney TG, Hall GA, Thomas LH, Parsons KR: Studies on the relationship between coronaviruses from the intestinal and respiratory tracts of calves. Arch Virol 85: 71-83, 1985.

15) Saif LJ: Coronavirus immunogens. Vet Microbiol 37: 285-297, 1993.

16) Sato K, Inaba Y, Matumoto M: Serological relation between calf diarrhea coronavirus and hemagglutinating 
encephalomyelitis virus. Arch Virol 66: 157-159, 1980.

17) Takamura K, Okada N, Ui S, Hirahara T, Shimizu Y: Protection studies on winter dysentery caused by bovine coronavirus in cattle using antigens prepared from infected cell lysates. Can J Vet Res 64: 138-140, 2000.

18) Taniguchi S, Iwamoto H, Fukuura H, Ito H, Kaige $\mathbf{N}$, Nagoto $Y$ : Recurrence of bovine coronavirus infection in cows. J Jpn Vet Med Assoc 39: 298-302, 1986.

19) Timoney JF, Gillespie JH, Scott FW, Barlough: Bovine coronavirus infection. Pp 902-905. In Hagan and Bruner's microbiology and infectious diseases of domestic animals, $8^{\text {th }}$ ed. Cornell University Press, New
York, 1988.

20) Traven M, Bjornerot L, Larsson B: Nationwide survey of antibodies to bovine coronavirus in bulk milk from Swedish dairy herds. Vet Rec 144: 527-529, 1999.

21) Tsunemitsu H, el-Kanawati ZR, Smith DR, Reed HH, Saif LJ: Isolation of coronaviruses antigenically indistinguishable from bovine coronavirus from wild ruminants with diarrhea. J Clin Microbiol 33: 3264 $-3269,1995$.

22) Tsunemitsu H, Saif LJ: Antigenic and biological comparisons of bovine coronaviruses derived from neonatal calf diarrhea and winter dysentery of adult cattle. Arch Virol 140: 1303-1311, 1995. 